|Araştırma Makalesi / Research Article |

\title{
Argümantasyon Tabanlı Bilim Öğrenme Yaklaşımının ilkokul Öğrencilerinin Akademik Başarılarına ve Argümantasyon Kalite Düzeylerine Etkisi ${ }^{1}$
}

\section{The Effect of Argumentation Based Science Learning Approach on the Academic Achievement and Argumentation Quality Levels of Primary Students}

\author{
Serpil Kara², Serkan Yılmaz ${ }^{3}$, Sevgi Kıngır ${ }^{4}$
}

Anahtar Kelimeler
argümantasyon tabanlı
bilim öğrenme
başarı
argümantasyon kalitesi
fen eğitimi
kuvvet

\section{Keywords}

argumentation based science learning

achievement

quality of argumentation

science education

force

Başvuru Tarihi/Received

11.05.2019

Kabul Tarihi /Accepted

06.02.2020

\section{Öz}

Bu çalışmanın amacı, Argümantasyon Tabanlı Bilim Öğrenme (ATBÖ) yaklaşımının dördüncü sınıf öğrencilerinin "Kuvvetin Etkileri" ünitesindeki başarıları üzerindeki etkisini ve АТВÖ yaklaşımı ile işlenen derslerde öğrencilerin yazılı argümantasyon kalite düzeylerini incelemektir. Araştırmada, nicel araştırma yöntemlerinden, ön-test son-test kontrol gruplu yarı deneysel araştırma deseni kullanılmıştır. Bu çalışma, 2017-2018 eğitim ve öğretim yılı güz döneminde Konya ilinde bulunan bir ilkokulda gerçekleştirilmiştir. Çalışmaya, dördüncü sınıfta öğrenim görmekte olan toplam 45 öğrenci katılmıştır. Veri toplama araçları olarak "Kuvvetin Etkileri Ünitesi Başarı Testi" ve "Holistik Argüman Puanlama Ölçeği" kullanılmıştır. Yapılan ANCOVA analizi sonucunda deney grubu lehine anlamlı bir fark görülmüştür. Bulgular, ATBÖ yaklaşımın öğrencilerin "kuvvetin etkileri" ünitesinde başarılarını olumlu etkilediğini göstermektedir. Deney grubundaki öğrencilerin yazııı argümantasyon kalite düzeyini tespit edebilmek için öğrenci etkinlik raporları incelenmiş ve incelenen genel toplam puanların ortalaması ışı̆ı̆nda "orta düzey" bir kalitede olunduğu sonucuna ulaşıımışıı. ATBÖ yaklaşımının kullanılması ile öğrencilerin yazılı argümantasyon kalite düzeylerini arttırmanın mümkün olacağı söylenebilir. Dolayısıyla yazıı argümantasyon kalite düzeyinin artması ile öğrencilerin akademik başarılarının da artacağı öngörülmüştür. Bu bağlamda, ATBÖ yaklaşımının ilkokulda hatta eğitim fakültelerinde öğretmen yetiştirme programlarında kullanılması önerilmektedir.

\section{Abstract}

The aim of this study is to examine the impact of Argumentation Based Science Learning (ABSL) approach on the achievement of fourth grade students in the "Effects of Force" unit and to examine the students' written quality argumentation levels in the courses taught by the ABSL approach. Pre-test post-test control group design was used in this quasi-experimental study. This research was conducted in a primary school in the province of Konya in the fall semester of 2017-2018 academic year. Forty-five students from the fourth year were participated in the study. "Effects of Force Unit Achievement Test" and "Holistic Argument Scoring Scale" were used as data collection tools. ANCOVA results showed a significant difference in favor of the experimental group. The findings show that ABSL approach positively affects the achievements of the students in the "Effects of Force" unit. With the aim of identifying experimental group students' quality level of the written argumentation, the student activity reports were examined and in the light of the average of the overall total scores examined, it was concluded that it was of a "medium level" quality. It is possible to say that the quality levels of the students' written argumentation can be increased. Thus, it can be concluded that the academic achievements of the students will increase with the increase in the quality level of written argumentation. In this context, it is recommended that the ABSL approach should be used at the primary school level and even in teacher training programs of the education faculties.

\footnotetext{
${ }^{1}$ Bu çalışmanın bazı kısımları “European Conference on Educational Research (ECER) , 2018” de sözlü bildiri olarak sunulmuştur.

${ }^{2}$ Necmettin Erbakan Üniversitesi, Ahmet Keleşoğlu Eğitim Fakültesi, Matematik ve Fen Bilimleri Eğitimi Bölümü, Konya, TÜRKiYE; https://orcid.org/0000-00022973-2075

${ }^{3}$ Hacettepe Üniversitesi, Eğitim Fakültesi, Matematik ve Fen Bilimleri Eğitimi Bölümü, Ankara, TÜRKiYE; https://orcid.org/0000-0003-1800-0765

${ }^{4}$ Hacettepe Üniversitesi, Eğitim Fakültesi, Temel Eğitim Bölümü, Ankara, TÜRKiYE; https://orcid.org/0000-0003-1848-4392
} 
Extended Abstract

\section{Introduction}

The basic subjects of the physics course, which is one of the fundamental areas of science education and which can be very difficult for students in general, begin with the subject of "force". Studies show that students have various alternative conceptions about "force and motion". For this reason, it is thought that it is important to enable the students to ask questions, to do research, to express their thoughts, to construct arguments and to participate in discussions and conversations in classroom learning environment. In this context, one of the methods that can contribute to the achievements of students is the Argument Based Science Learning (ABSL) approach.

This approach involves inquiry-based applications (Cavagnetto, 2010). The ABSL promotes students' critical thinking skills and thus facilitates understanding of science-related concepts (Ceylan, 2012). In a learning environment based on the ABSL approach, a procedure using "question /claim/evidence" structure is followed. Students construct knowledge via questioning, observing, conducting researches, and generating evidence and claims. Accordingly, this approach includes two basic outlines on behalf of students and teachers (Norton-Meier, Hand, Hockenberry, \& Wise, 2008). Individual, within group and in-class negotiations support meaningful learning and increase the degree of knowledge retention (Norton-Meier et al., 2008). While the skills of individuals such as analytical thinking, decision-making, communication and teamwork are improved through oral argumentation and individual and in-class negotiations, the written argumentation is encouraged and meaningful learning is supported. Writing process promotes internal learning (Mason \& Boscolo, 2000), and therefore, writing activities are of great convenience in learning difficult science related concepts (Hohenshell \& Hand, 2006).

In this context, there is limited research conducted with primary school students. For this reason, this work was needed in order to start developing the argumentation skills at the primary school level and to fill a gap in this field. The first aim of this research is to determine the impact of using ABSL approach in the unit of "Effects of Force" on fourth graders' academic achievement. The second aim is to determine students' quality levels of written argumentations in the courses, which are taught by the ABSL approach.

\section{Method}

Pre-test post-test control group quasi-experimental design was utilized in this research. This study was conducted in a primary school in the province of Konya in the fall semester of 2017-2018 academic year. Forty-five students (22 in experimental and 23 in comparison group) from the fourth grade were participated in this research. "Effects of Force Unit Achievement Test" and "Holistic Argument Scoring Scale" were used as data collection tools. This achievement test was applied as a pre-test to the groups before implementation of the ABSL approach. According to the independent t-test, it was decided that the academic achievements of the two classes was equivalent. Thus, one of the groups was randomly assigned to the experimental and the other to the control group. The implementation lasted three weeks throughout the unit and three hours per week, and the study was completed in five weeks with the inclusion of pre-test and post-test administrations. In the experimental group, due to implementation of the ABSL approach, the lesson plans were prepared by the teacher and one of the researchers by taking into consideration ABSL teacher template and the lesson plans were implemented by the teacher accordingly. The experimental group was divided into five groups and each subgroup engaged in three ABSL activities. The ABSL report format has been prepared by considering the ABSL student template and written argumentation quality levels have been obtained assessing this report. The ABSL report format has been filled out three times throughout the study by the students individually. Descriptive statistics and ANCOVA were used for the analysis of the data.

\section{Result and Discussion}

ANCOVA results showed a significant difference in favor of the experimental group. The findings show that ABSL approach positively affects the achievements of the students in the "Effects of Force" unit. The eta square value calculated for the effect size was found to be 0.192 and corresponds to the large effect size according to Green and Salkind (2014). In addition, the power of the study was calculated 0.869. These findings show that the effect of the ABSL approach on the achievement of students in the unit of "Effects of Force" is both statistically and practically significant. With the aim of identifying experimental group students' quality level of the written argumentation, the student activity reports were examined and in the light of the average of the overall total scores identified, it was concluded that it was of a "medium level" quality. This result is in line with the results of Choi et al. (2010). As the numbers in the activities related to argumentation increased, the results of the students' ability to produce arguments were improved (Yaman, 2018). In this study, which was conducted in one unit and limited time, it is observed that increasing the argumentation skills of the students with increasing activities supports other studies. The use of written and verbal argumentation is of great importance in terms of treating science as a scientist in understanding and expressing scientific facts while providing science teaching in early age groups (Simon \& Johnson, 2008). This study was conducted with the fourth grade students in the literature mentioned as early age groups and showed that the argumentation activities could be effective in early age groups and science education. In this context, it is recommended that the ABSL approach should be used in the context of primary schools and even in teacher training programs of the education faculties. 
GiRiş

Fen bilimlerinin temel alanları genel olarak fizik, kimya ve biyoloji olarak nitelendirilmekte olup, öğrencilerin daha çok zorlandıkları alan "fizik" olarak tespit edilmiştir (Macaroğlu ve Şentürk, 2001; Özmen, Dumanoğlu ve Ayas, 2000; Sönmez, Geban ve Ertepınar, 2001). Fizik alanının temel konuları ise "kuvvet" konusu ile başlamaktadır. Yapılan çalışmalarda ilkokuldan üniversiteye farklı sınıf seviyelerindeki öğrencilerin "kuvvet ve hareket" konusunda yanlış ya da eksik öğrenmelere sahip oldukları tespit edilmiştir (Allen, 2010; Anggoro, Widodo, Suhandi ve Treagust, 2019; Champagne, Klopfer ve Anderson, 1980; Çepni, Aydın ve Ayvacı, 2000; Nuhoğlu, 2008; Palmer, 2001).

Genel olarak fen bilimleri alanındaki eksiklikler, eğitim öğretim sistemimizin ve çıktılarının değerlendirilmesi amacıyla öğrencilerin katıldığı uluslararası düzeyde yapılan değerlendirme sınavları TIMSS ve PISA sonuçlarına da yansımaktadır. Uluslararası alanda yapılan TIMSS ve PISA sınavları öğrencilerin sadece programda yer alan bilgileri ne kadar iyi öğrendiklerini değil, aynı zamanda okuduğunu anlama, yorumlama, değerlendirebilme ve başka alanlarda kullanabilme gibi becerilerini de ölçmektedir. Diğer bir ifade ile sınavlarda ölçülmek istenen durum, öğrencilerin öğrendiklerini günlük yaşamda kullanma ve değerlendirebilme becerileri olarak düşünülebilir. Yine Ekonomik Kalkınma ve İşbirliği Örgütü (OECD, 2014) raporlarına göre üç yılda bir yapılan PISA sınavı sonuçlarında Türkiye ortalamanın altında kalmaktadır. PISA sınav sorularının birçoğunun özelliği akıl yürütmeye ve yoruma dayalıdır. Bu özelliği dikkate alınarak PISA sonuçları değerlendirildiğinde ise öğrencilerin bilgiyi öğrenme, yaratıcı çözüm yolları geliştirebilme ve uygulayabilme boyutunda becerilerinin geliştirilmesi için araştıran sorgulayan, topluma ve insanlığa faydalı becerilerin ortaya konulmasına imkân sağlayacak, yeni fikirler üretebilmelerine yardımcı olacak yaklaşımların kullanılmasına ihtiyaç duyulmaktadır. Bu doğrultuda geliştirilen öğretim programlarında ifade edilen "inovatif düşünme becerisi” yeni bakış açılarına, özgün yaklaşımlara, yeni kavrayışlara, olgu ve olayların anlaşılması ve kavranmasında yeni yollara öncülük eden bir düşünme biçimidir. Bu düşünme biçiminin geliştirilmesinde önemli olan, kişilerin fikir üretimini sağlayacak tekniklerin kullanılması, farklı fikirlerin ortaya atılması, hayal gücüne, düşünme becerilerinin geliştirilmesine dayalı eğitimin sağlanabilmesidir (MEB, 2017).

Bireyleri soru sormaya, keşifler yapmaya, bilimsel bilgiye ulaşmaya ve bu bilimsel bilgiyi çeşitli problemlere uygulama, düşünme yeteneklerini kullanma gibi durumları kapsayan araştırma-sorgulama süreci, sadece "keşfetme ve deney" olarak değil, "açıklama ve argüman" oluşturma süreci olarak da ele alınmaktadır. Yeni fikirlerin ortaya çıkarılmasında etkili olan araştırma-sorgulamaya dayalı öğrenme ortamlarında benimsenen strateji ve yöntemlerde, öğretmenlerin rolü, öğrencilerin fikirlerini rahatlıkla ifade edebildikleri, düşüncelerini farklı gerekçelerle destekleyebildikleri ve arkadaşlarının iddialarını çürütmek amacıyla karşıt argümanlar geliştirebildikleri diyaloglar içerisinde yer almalarını sağlamaktır. Karşıt argümanları içeren sözlü veya yazılı tartışmalarda öğretmenler, öğrencilerinin geçerli verilere göre oluşturdukları iddiaları, haklı gerekçelerle sundukları tartışmalarda yönlendirici ve rehber rolü üstlenmektedirler (MEB, 2013).

Argümantasyon Tabanlı Bilim Öğrenme (ATBÖ) yaklaşımı, araştırma-sorgulama tabanlı uygulamalarla birleştirilmiştir (Cavagnetto, 2010). ATBÖ yaklaşımı ile araştırma sorgulama yapılırken "soru-iddia-kanıt" sürecini içeren bir yöntem izlenmektedir. Bireyi merkeze alan öğrenme kuramının temel işlevlerinin üzerine bilimsel argümantasyonu ve okuma-yazma gibi dil etkinliklerini yapılandırarak, Keys, Hand, Prain ve Collins (1999) orijinal adı, "Science Writing Heuristic" olan ve daha sonra "Argümantasyon Tabanlı Bilim Öğrenme" olarak dilimize adapte edilen yaklaşımı öngörmüşlerdir (Günel, Kıngır ve Geban, 2012). ATBÖ yaklaşımı ile öğrenciler bilgiyi, sorular sorarak, deney ve gözlemler yaparak, iddia ve deliller oluşturarak, araştırma-sorgulama yolu ile yapılandırmaktadırlar. Bu bağlamda ATBÖ yaklaşımı, öğretmen ve öğrencilere yönelik iki şablon içermektedir (Norton-Meier, Hand, Hockenberry ve Wise, 2008). Tablo 1'de verilen öğretmenler için önerilen şablonun öğretmenlerin ders planlarını hazırlarken ATBÖ yaklaşımın temel kriterlerini göz önünde bulundurmalarını sağlayacak bir rehber olması öngörülmüştür.

\section{Tablo 1. ATBÖ öğretmen şablonu}

1. Bireysel ya da grup olarak kavram haritası yoluyla ön bilgilerin ortaya çıkarılması

2. İnformal yazma, gözlem yapma, beyin fırtınası ve soru sorma tekniklerinin kullanıldığı laboratuvar öncesi aktiviteler

3. Laboratuvar etkinliklerine katılım

4. I. müzakere fazı - Laboratuvar etkinliklerinde kişisel yazma faaliyetlerinin yapılması (Örneğin, günlük yazma)

5. II. müzakere fazı - Küçük gruplarda gözlemlerden elde edilen verilerin yorumlarının paylaşımı ve kıyaslanması (Örneğin, grup olarak taslak oluşturma)

6. III. müzakere fazı - Düşüncelerin kitap ya da diğer kaynaklar ile karşılaştırılması (Örneğin, başlangıç sorularını cevaplandırmaya yönelik grup notu çıkarma)

7. IV. müzakere fazı - Bireysel yansıma ve yazma faaliyetlerin yapılması (Örneğin, bilgi verecek kişiler için rapor ya da poster gibi sunum hazırlama)

8. Kavram haritası yoluyla öğretim sonunda öğrenilenlerin ortaya çıkarılması

Tablo 2'de izlenilecek adımları ifade edilen öğrenci şablonu ise öğrencilerin belirledikleri sorular ile başlayan ve argümantasyonun genel yapısını oluşturan soru-iddia-delil öğeleri üzerine yapılandırılan ve süreç içerisinde öğrencinin fikirlerindeki değişimi açıklayan yansıma bölümü ile tamamlanan aktif bir yapıya sahiptir. Bu bakımdan hem araştırma sorgulama etkinliklerini planlı takip etmelerinde hem de etkinlik sonucu araştırma raporlarını yazmaları konusunda rehber çerçeve niteliğindedir (Hand, Norton-Meier, Staker ve Bintz, 2009). Bilimsel bilgiler ve gözlemler arasında bir köprü oluşturmak için pratik 
çalışmaların yetersiz olduğu, uygulamaların yanı sıra yazılı söylemlere de ihtiyaç olduğu vurgulanmaktadır (Wellington ve Osborne, 2001). Bir sorunun çözümüne ve genel bir çıkarımın yapılmasına yönelik araştırma, sorgulama, gözlem ve ölçüm yapılmasının yanı sıra, muhakeme, konuşma ve yazmanın etkileşiminin öğrenciye yeni fırsatlar sağlayabileceği ifade edilmiştir (Lemke, 1990). Birçok çalışma, öğrenciler için kullanılan yazma şablonunun anlamlı öğrenmeyi geliştirmek için öğrenciye yardım ettiğini vurgulamaktadır (Hand, Wallance ve Yang, 2004; Keys ve diğ., 1999). Yapılandırılmış bir yazma şablonunun verilmesinin öğrencilerin argümantasyon becerilerini daha iyi geliştirdiği ve öğrencilerin akıl yürütmeleri ve bilimsel sorgulama aktivitelerine kılavuzluk ettiği ifade edilmektedir (Hand, 2008; Jang ve Hand, 2017).

\section{Tablo 2. ATBÖ öğrenci şablonu}

1. Başlangıç düşünceleri- Sorularım nelerdir?

2. Testler- Ne yaptım?

3. Gözlemler- Ne gördüm?

4. İdialar- Ne iddia edebilirim?

5. Kanıt- Nasıl anladım? Niçin bu iddialarda bulunuyorum?

6. Okuma- Benim düşüncelerim başka düşüncelerle nasıl karşılaştırılır?

7. Yansıma- Düşüncelerim nasıl değişti?

ATBÖ yaklaşımının, diğer araştırma-sorgulamaya dayalı öğrenme yöntemlerinden en belirgin farkı argümantasyonu ön plana çıkaran müzakere süreçleridir. Chen ve Steenhoek (2013b), fen sınıflarında argümantasyonu desteklemek üzere önermiş oldukları müzakere döngüsünü, öğrenciler tarafından bir araştırma sorusunun belirlenmesi, grup olarak bu araştırma sorusu hakkında araştırma yapmaları, grup olarak sorularına yönelik bir argüman sunulması, argümanlarını kitap ve diğer kaynaklarla karşılaştırması, argümanlarını revize etmesi ve bireysel yazma yoluyla öğrendiklerini yansıtması olarak tanımlamaktadırlar. Bilgilerin inşasında anlayarak öğrenme büyük önem taşımaktadır. Müzakere, öğrencinin kendi bilgileri ile akranlarının bilgilerinin etkileşmesi olarak tanımlanmakta olup, anlamlı öğrenmeyi desteklemekte ve bilgilerin kalıcılı̆ını da arttırmaktadır (Keys ve diğ., 1999; Norton-Meier ve diğ., 2008). Öğrencilerin derslerde bilimsel bilgileri anlayarak öğrenmesi temel amaçlardandır. Fen sınıflarında argümantasyonu desteklemek için bir müzakere döngüsü üzerine yapılan çalışmada, küçük grup müzakereleri ve büyük grup müzakereleri ile dersler yürütüldüğünde diğer gruplara göre, eleştirel düşünme becerilerinde büyük etki düzeyinde etki görüldüğü sonucuna ulaşılmıştır (Chen ve Steenhoek, 2013b). Yazarların başka bir çalışmasında ise, müzakere döngüsü kullanıldığında eleştirel düşünme becerilerinin yanında, kavramsal anlamayı geliştirdiği ve öğrencilerin bilimsel yazma becerilerini de desteklediği vurgulanmaktadır (Chen ve Steenhoek, 2013a).

Fen bilimleri derslerindeki öğrenme süreci; keşfetme, sorgulama, argüman oluşturma ve ürün tasarlamayı kapsamaktadır. Ayrıca fen bilimleri dersinde öğrencilerin düşüncelerini görsel, sözlü veya yazılı olarak açıklayarak iletişim ve yaratıc düşünme becerilerinin geliştirilmesine olanak sağlayan fırsatların öğrencilere sunulması beklenmektedir. Öğrencilerin fikirlerini rahatça açıklayabilmeleri, düşüncelerini farklı gerekçelerle destekleyebilmeleri ve arkadaşlarının iddialarını çürütmek amacı ile karşıt argümanlar oluşturabilmeleri için bilimsel olgulara yönelik yarar-zarar ilişkisini tartışabilecekleri ortamlar sağlanmalıdır (MEB, 2017). Argümantasyona dayalı sorgulama yönteminin kullanılması ile öğrencilerin akademik başarılarında ve argümantasyon seviyelerinde ilerlemeler gözlenmektedir (Aktaş ve Doğan, 2018). Kuhn (2010), bireyin kendi argümanını savunurken güven verici sözlerle destekleyerek, karşıt argümanı zayıflatmak için rakibine meydan okuyarak zayıf yanlarını söylemesi gibi argümantasyon kullanmanın önemini vurgulamaktadır.

Öğrencilerin fen dersleriyle tanıştığı ilköğretim yıllarında fen ile ilgili kavramları doğru anlayabilmesi ve öğrenebilmesi, ileri düzeydeki sınıflarda karşılaşacağı fen derslerine temel oluşturması bakımından oldukça önemli olduğu ifade edilmektedir (Simon ve Johnson, 2008). Argümantasyon tabanlı eğitim, öğrencilerin eleştirel düşünme becerilerini geliştirmekte ve dolaysıyla fen ile ilgili kavramların anlaşılmasında kolaylıklar sağlamaktadır (Ceylan, 2012). Argümantasyon, bilimde, fen eğitiminde önemli süreçlerden biri olduğu için, fen derslerinde bilimsel araştırma ve bilimsel okuryazarlığın bir parçası olarak öğretilmeli ve öğrenilmelidir (Erduran ve Jiménez-Aleixandre, 2007). Bu bağlamda, 2018 Fen Bilimleri Dersi Öğretim Programı "beceri” odaklı olup, bilimsel süreç becerileri, yaşam becerileri ve mühendislik ve tasarım becerileri üzerinde durulmaktadır (MEB, 2017). ATBÖ yaklaşımı ile bireyler, bahsedilen üç beceri alanında gelişim göstermektedir. Analitik düşünme, karar verme, iletişim ve takım çalışmaları gibi beceriler sözlü argümantasyon ile bireysel ve sınıf içi müzakereler yoluyla gelişirken yazılı argümantasyon ile pekiştirilmekte, kalıcı ve anlamlı öğrenmenin desteklenmesi sağlanmaktadır. İyi bir öğrenme aracı olarak yazma önerilmektedir (Chen, 2013a). Özellikle fen bilimleri eğitiminde yazmanın önemini vurgulayan ve iddia ve kanıt gibi temel argümantasyon yazım rehberi veya daha gelişmiş şablonları sunan kaynaklara rastlamak mümkündür (Hillocks, 2011; Norton-Meier ve diğ., 2008; Öğreten ve Uluçınar-Sağır, 2014). Yazma şablonları ile öğrencilerin, anlamlı bir öğrenme gerçekleştirdikleri ifade edilmektedir (Chen, 2013b; Fulwiler, 2011). Chen, Han ve Mcdowell (2013) öğrencilerin yazma ürünlerinin kaliteleri arttığı zaman, kavramsal anlamalarının da arttığı sonucuna ulaşmışlardır. Kaynaklarda bahsedilen ortak nokta, sözlü söylemlerin birbirinden farklı ve oldukça esnek olduğu, oysa yazılı söylemlerin kapsamlı, konuya daha odaklanmış ve daha fazla bilişsel aktiviteler gerektirdiğidir. Yazma işlemi, içsel öğrenmeyi hızlandırmakta (Mason ve Boscolo, 2000) ve dolayısıyla fen ile ilgili zor kavramların öğrenilmesinde yazma etkinlikleri büyük kolaylık sağlamaktadır (Hohenshell ve Hand, 2006).

Ulusal ve uluslararası alanyazın, ATBÖ yaklaşımının öğrencilerin kavramsal anlama ve argümantasyon becerileri gibi öğrenme çıktıları üzerinde olumlu etkilerinin olduğunu göstermektedir (Günel ve diğ., 2012; Hand ve diğ., 2017). İlgili araştırmalar 
öğrencilerin "kuvvet" ile ilgili kavramları anlamakta zorlandıklarını ve bu konuda çeşitli kavram yanılgılarının olduğunu da göstermektedir (Allen, 2010). Kara ve Aktürkoğlu (2019) tarafından yapılan bir araştırmada üçüncü sınıfların fen bilimleri ders kitabı, sözel ve görsel içerik açısından kavram yanılgılarına neden olabilecek özellikler bakımından incelenmiş ve "kuvvet" kavramıyla ilgili öğrencilerde yanılgıların oluşabileceği sonucuna ulaşılmıştır. Ayrıca ulusal düzeyde fen bilimleri konularında ilkokul düzeyinde yapılan çalışmalar, ortaokul ve lise düzeyinde yapılan çalışmalara göre sınırlıdır. Örneğin Türkiye'de ilkokul düzeyindeki öğrencilerle yapılan tezlerin yaklaşık \%1,3 (Kabataş-Memiş, 2017), makale çalışmalarının ise yaklaşık \%17 (Bağ ve Çalık, 2017) oranında olduğu tespit edilmiştir. Okul ortamında öğrenciler kuvvet kavramı ile ilk kez ilkokulda karşılaşmaktadır. illkokul döneminde ATBÖ yaklaşımı kullanılarak öğrencilerin kuvvet konusundaki kavramlarının ve argümantasyon becerilerinin geliştirilmesinin öğrencilerin sonraki fen konularını öğrenmelerine katkıda bulunacağı düşünülmektedir.

Bu nedenlerle bu çalışmanın amacı; АTBÖ yaklaşımının "Kuvvetin Etkileri” ünitesinde kullanılmasının dördüncü sınıf öğrencilerinin akademik başarıları üzerindeki etkisini incelemektir. Bir diğer amaç ise ATBÖ yaklaşımı ile işlenen derslerde öğrencilerin yazılı argümantasyon kalite düzeylerini tespit etmektir. Bu bağlamda araştırma soruları şu şekilde belirlenmiştir:

- АTBÖ yaklaşımının “Kuvvetin Etkileri” ünitesinde kullanılmasının 4. sınıf öğrencilerinin akademik başarıları üzerinde etkisi var mıdır?

- $\quad$ ATBÖ yaklaşımı ile işlenen derslerde öğrencilerin yazılı argümantasyon kalite düzeyleri nasıldır?

\section{YÖNTEM}

Bu bölümde sırasıyla araştırma deseni, çalışma grubu, veri toplama araçları, uygulama süreci ve verilerin analizi bilgilerine yer verilmiştir.

\section{Araştırma Deseni}

Bu çalışmada nicel araştırma desenlerinden ön-test, son-test kontrol gruplu yarı deneysel araştırma deseni kullanıl-mıştır. Yarı deneysel çalışmalar, rastlantısal olmadan tasarlanmış olup, müdahaleli çalışmalar olarak tanımlanmakta-dır (Fraenkel ve Wallen, 2006).

\section{Çalışma Grubu}

Bu çalışma, 2017-2018 eğitim ve öğretim yılı 1. yarıyıl döneminde Konya ilindeki özel bir ilkokulda yapılmıştır. Araştırmada, kolay ulaşılabilir durum örneklemesi yöntemi kullanılmıştır. Katılımcılara kolay bir şekilde ulaşılarak, enerji, zaman ve maddi kaynak tasarrufu sağlayarak, çalışmaya pratiklik ve hız kazandırmasından dolayı bu örnekleme yöntemi tercih edilmiştir. Çalışma grubunu oluşturan dördüncü sınıf öğrencileri, iki şubeden oluşmaktadır. Grupların rastgele atandığı bu çalışmaya, 22'si deney, 23'ü ise kontrol grubunda olmak üzere toplam 45 öğrenci katılmıştır. Çalışma grubundaki öğrencilere ait bilgiler Tablo 3'te yer almaktadır.

Tablo 3. Çalışma grubunu oluşturan öğrencilerin gruplara göre cinsiyet dağılımları

\begin{tabular}{lccc}
\hline Gruplar & Cinsiyet & $f$ & $\%$ \\
Deney & Kız & 13 & 59.1 \\
& Erkek & 9 & 40.9 \\
\hline \multirow{2}{*}{ Kontrol } & Toplam & 22 & 100 \\
& Kız & 10 & 43.5 \\
\hline
\end{tabular}

\section{Veri Toplama Araçları}

Bu çalışmada verilerin toplanmasında Kuvvetin Etkileri Ünitesi Başarı Testi ve Holistik Argüman Puanlama Ölçeği kullanılmıştır.

\section{Kuvvetin Etkileri Ünitesi Başarı Testi}

Bu çalışmada öğrencilerin fen başarılarını ölçmek amacı ile araştırmacılar tarafından "Kuvvetin Etkileri Ünitesi Başarı Testi" (KEÜBT) hazırlanmıştır. KEÜBT, her bir soruda dörder seçenek olmak üzere, 20 çoktan seçmeli sorudan oluşmaktadır. Test soruları ünitenin kazanımları dikkate alınarak çeşitli soru havuzlarından faydalanılarak hazırlanmıştır. KEÜBT için yapılan geçerlik ve güvenirlik çalışmalarının sonucunda hazırlanmış olan soruların kazanımlara göre dağılımı Tablo 4'te sunulmuştur.

Tablo 4. Testte yer alan soruların kazanımlara göre dağılımları

\begin{tabular}{lc}
\hline Kazanımlar & Testte Yer Alan Sorular \\
\hline Kuvvetin, cisimlere hareket kazandırmasına ve cisimlerin şekil değiştirmesine yönelik deneyler & $1,2,3,4,5,6,7,8,9,10$ \\
yapar. & $11,18,19,20$ \\
Mıknatısı tanır ve kutupları olduğunu keşfeder. & $12,15,17$ \\
Mıknatısın etki ettiği maddeleri deney yaparak keşfeder. & 13,16 \\
Mıknatısların günlük yaşamdaki kullanım alanlarına örnekler verir. & 14 \\
Mıknatısın yeni kullanım alanları konusunda fikirleri açıklar. & \\
\hline
\end{tabular}


Ölçme aracı olarak, kullanılan KEÜBT için araştırmacılar tarafından yapılan geçerlik ve güvenirlik çalışmaları şu şekildedir: Başarı testi için öncellikle, ünitenin kazanımları dikkate alınarak 26 sorudan oluşan, dört seçenekli çoktan seçmeli bir test hazırlanmıştır. Testin kapsam geçerliği için fen eğitimi alanında çalışmakta olan üç öğretim üyesine gönderilerek uzman görüşleri alınmıştır. Bu görüş ve öneriler doğrultusunda test düzenlenerek, testin geçerlik ve güvenirlik analizlerinin yapılabilmesi için bir özel okuldaki ulaşılabilen toplam 30 beşinci sınıf öğrencisine uygulanmıştır. 5. sınıf öğrencileri, ilgili ünite hakkında deneyim sahibi oldukları için tercih edilmiştir. Doğru cevaplar için ' 1 ', yanlış ve boş cevaplar için ' 0 ' puan verilerek öğrenci puanları hesaplanmıştır. Alt ve üst gruplar oluşturulmuş her bir madde için madde ayırt ediciliği ve madde güçlük indeksleri hesaplanmıştır. Madde güçlük indeksinin başarı testlerinde 0,50 civarında olması testin orta zorlukta olduğu ve arzu edilenin de bu şekilde olduğu belirtilmektedir (Çepni ve diğ., 2008). Geçerlik ve güvenirlik analizleri kapsamındaki uygulama neticesinde, indeks değeri 0,50 altında olan $5,6,11,21,23$ ve 24. soruların zor sorular olduğu tespit edilmiştir. Madde ayırt edicilik indeksi 0,20 altında olan 2, 3, 4, 10, 15 ve 23 . sorular ise testten çıkarılmıştır. İki, üç ve dördüncü soruların ayırıcılık gücü 0,00 çıkarken, 23. sorunun değeri ise negatif çıkmıştır. Geçerlik çalışmalarından sonra son hali ile 20 soru olan başarı testinin güvenirliği SPSS programı ile hesaplanmış ve Cronbach alfa katsayısı 0,73 olarak bulunmuştur.

\section{Holistik Argüman Puanlama Ölçeği}

Deney grubundaki her bir öğrenci tarafından doldurulan ATBÖ raporlarını değerlendirerek yazılı argümantasyon kalite düzeyini tespit edebilmek için, Choi, Notebaert, Diaz ve Hand (2010) tarafından geliştirilen ve Tablo 5 'te verilen puanlama ölçeği kullanılmıştır. Bu ölçekte, öğrencilerin yazılı argümantasyon kalitesi beş düzeyde değerlendirilmiş olup alınabilecek toplam puan 2-10 arasında değişmektedir. Ölçek yardımıyla her bir öğrenci tarafından doldurulan ATBÖ raporlarının incelenmesiyle, öğrencilerin yazılı argümantasyon kalite düzeyleri tespit edilmiştir.

\section{Tablo 5. Holistik Argüman Puanlama Ölçeği}

\begin{tabular}{|c|c|c|}
\hline Puan & Argümantasyon Kalitesi & Kriterler \\
\hline 2 & Çok zayıf & $\begin{array}{l}\text { - Test edilemeyen soru, geçersiz iddia, uygun olmayan kanıt ve yansıma } \\
\text { - Soru, iddia ve kanıt arasında çok zayıf ilişki }\end{array}$ \\
\hline 4 & Zayıf & $\begin{array}{l}\text { - Test edilemeyen soru, geçersiz iddia, uygun olmayan kanıt ve yansıma } \\
\text { - Soru, iddia ve kanıt arasında çok zayıf ilişki olabilir }\end{array}$ \\
\hline 6 & Orta & $\begin{array}{l}\text { - Önemli soru, yeterli iddia, uygun kanıt ve yansıtma } \\
\text { - Soru, iddia ve kanıt arasında orta düzeyde ilişki }\end{array}$ \\
\hline 8 & Güçlü & $\begin{array}{l}\text { - Önemli soru, geçerli iddia, güçlü kanıt ve anlamlı yansıtma } \\
\text { - Soru, iddia ve kanıt arasında güçlü ilişki }\end{array}$ \\
\hline 10 & Çok güçlü & $\begin{array}{l}\text { - Asıl gerekli soru, çok sesli iddialar, çok güçlü kanıt ve çok anlamlı yansıma } \\
\text { - Soru, iddia ve kanıt arasında çok güçlü ilişki }\end{array}$ \\
\hline
\end{tabular}

Bu ölçeğin güvenirliğini sağlamak için öncelikle öğrenci ATBÖ raporları arasından rastgele 13 rapor seçilmiştir. Bu raporlar birbirinden bağımsız olarak, bir öğretim üyesi ve bir öğretim elemanı tarafından ayrı ayrı puanlanmış ve aralarında puan uyumuna bakılmıştır. Aralarında uyum sağlanıncaya kadar öğrenci kâğıtları puanlamaya devam edilmiştir. Puanlayıcılar arasındaki uyum \%86 olarak sağlanınca, geriye kalan kâğıtlar araştırmacılardan biri tarafından puanlanarak tamamlanmıştır. Puanlayıcılar arasındaki uyum en az \%80 olduğunda güvenirlik yüzdesine ulaşılmış kabul edilmektedir (Fraenkel, Wallen ve Hyun, 2012).

\section{Uygulama Süreci}

Uygulama öncesinde gruplara başarı testinin ön-test olarak uygulanması sonucu iki grup arasında bağımsız t-testi sonuçlarına bakılmış ve istatistiksel olarak anlamlı bir fark bulunmadığı anlaşılmıştır. Böylece iki şubenin akademik başarılarının denk olduğuna karar verilmiş olup gruplardan biri rastgele deney, diğeri ise kontrol grubu olarak atanmıştır. Ön-testin uygulandığı haftadan bir sonraki hafta uygulamaya başlanılmıştır. Deney grubunda "Kuvvetin Etkileri" ünitesi ATBÖ yaklaşımı kullanılarak işlenirken kontrol grubunda aynı ünite öğretim programının öngördüğü şekilde işlenmiştir. Uygulama, ünite boyunca üç hafta ve her hafta üçer ders saati olmak üzere sürmüş olup ön-test ve son-testin uygulandığı haftaların da dâhil olmasıyla toplam beş haftada çalışma tamamlanmıştır. Deney ve kontrol grubunda yapılan uygulamalar Tablo 6'da verilmiştir.

Tablo 6. Uygulama süreci

\begin{tabular}{lll}
\hline Hafta & Deney grubu & Kontrol grubu \\
\hline 1. & - Ön-test uygulaması & - Ön-test uygulaması \\
& - ATBÖ yaklaşımı hakkında sunum, gizemli olay etkinliği, & \\
& - Kuvvetin cisimler üzerinde şekil değişikliği etkisi & - Kuvvetin cisimler üzerinde şekil değişikliği etkisi \\
2. & - Her bir alt grubun araştırma sorusu belirlemesi & - Ders kitabından öğretmenin konuyu \\
& - Araştırma soruları kapsamında deney yapmaları & anlatması \\
& - ATBÖ rapor formatının doldurulması & ile ilgili video izlenmesi
\end{tabular}




\begin{tabular}{lll}
\hline Hafta & Deney grubu & Kontrol grubu \\
\hline & - Kuvvetin cisimler üzerinde hareket değişikliği etkisi & - Kuvvetin cisimler üzerinde hareket \\
& - Her bir alt grubun araştırma sorusu belirlemesi & deģikliği etkisi \\
3. & - Araştırma soruları kapsamında deney yapmaları & - Ders kitabından öğretmenin konuyu \\
& - Yapmış oldukları deneye ait gözlemleri sonucu iddia ve delil üretmeleri & anlatması \\
& - ATBÖ rapor formatının doldurulması & - Konu ile ilgili etkinlik yapılması \\
& - Mıknatısın tanıtılması ve kuvvetle ilişkisinin belirlenmesi & - Mıknatıs ve kuvvetle ilişkisi \\
& - Her bir alt grubun araştırma sorusu belirlemesi & - Ders kitabından öğretmenin konuyu \\
4. & - Araştırma soruları kapsamında deney yapmaları & anlatması \\
& - Yapmış oldukları deneye ait gözlemleri sonucu iddia ve delil üretmeleri & - Konu ile ilgili video izlenmesi \\
& - ATBÖ rapor formatının doldurulması & - Konu ile ilgili soru çözümü \\
\hline & - Son-test uygulaması & - Son-test uygulaması \\
\hline
\end{tabular}

Deney grubunda, ders planları ATBÖ öğretmen şablonu dikkate alınarak öğretmen ve araştırmacı tarafından birlikte hazırlanmış ve dersler ona uygun olarak yürütülmüştür. Deney grubunda, ilk hafta 'Gizemli bir olay: Bay Deniz, merdivenlerden düştü mü, düşürüldü mü?’ etkinliği (Bkz. Ek-1) ile ATBÖ yaklaşımı tanıtılmıştır. Bu hikâye ile öğrencilerin, argümantasyonun temel bileşenleri 'soru, iddia ve delil' kavramlarını düşünmeleri ve bunları bireysel olarak değerlendirdikten sonra tüm sınıf tartışarak öğrenmeleri pekiştirilmiştir. ATBÖ yaklaşımını uygulamak üzere, sınıf öğretmeninin de yardımıyla, her grupta kız-erkek, konuşkan-sessiz, başarılı-daha az başarılı gibi öğrencilerin yer aldığı heterojen toplam beş grup oluşturulmuştur. Üç grupta dörder öğrenci, iki grupta ise beşer öğrenci yer almış ve uygulama boyunca tüm öğrenciler kendi gruplarında sabit kalmışlardır.

Öğretmen şablonunda belirtildiği gibi, öğrencilerin ön bilgilerini ortaya çıkarmak amacıyla, farklı giriş etkinlikleri yapılabilmektedir. Giriş etkinlikleri olarak, ikinci ve üçüncü hafta sınıfa konunun içeriğine uygun olarak çeşitli materyaller getirilmiş ve oluşturulan beş grubun her birinin masalarına yerleştirilerek öğrencilerle, bu maddelerin kuvvet ile ilişkisi hakkında yorum, sorucevap gibi ön sınıf tartışmaları (fikir alışverişleri) yapılmıştır. Örneğin ikinci hafta, farklı değerdeki kütleler, pet şişeler, tahta çubuk kaşıklar, oyun hamurları, kurşun kalemler, ambalaj lastikleri, bulaşık süngerleri, oyuncak arabalar ve yaylar gibi malzemeler sınıfa getirilmiş; bu malzemelerden hangilerinin nasıl kullanılarak kuvvetin şekil değişikliğine etkisinin araştırılabileceği tartışılmıştır. Üçüncü hafta ise aynı malzemelerle kuvvetin harekete etkisinin nasıl test edileceği üzerinde fikir alışverişleri yapılmıştır. Dördüncü hafta ise, 'gizemli kutu' etkinliği giriş etkinliği olarak uygulanmıştır. Kapalı bir kutunun içine mıknatısın çektiği ve çekmediği maddeler konularak, kutuya açılan bir delikten maddelere yaklaştırılan mıknatıs ile hangi maddelerin mıknatıs tarafından çekildiği, hangi maddelerin çekilmediği denenmiş ve tüm sınıf olarak öğrencilerle sebepleri değerlendirilmiştir. Giriş etkinliklerinden sonra her bir grup kendi araştırma sorusunu belirlemişler. Tablo 7'de her bir grubun, her hafta oluşturdukları araştırma sorularının bilgisi yer almaktadır.

Tablo 7. Konu içeriğine göre deney grubundaki alt grupların belirledikleri araştırma soruları

\begin{tabular}{lcl}
\hline Konular & Gruplar & Araştırma soruları \\
\hline \multirow{2}{*}{ Kuvvetin şekil değişikliği etkisi } & 1. & Bir yaya uygulanan kuvvet değişirse yayın şeklinde değişiklik olur mu? \\
& 2. & Kuvvet etkisi ile şekil değişikliği her maddede aynı mıdır? \\
& 3. & Her maddenin esnekliği aynı mıdır? \\
Kuvvetin hareket değişikliği etkisi & 5. & Her madde aynı şekilde mi esner? \\
& 1. & Kuvvet her maddenin şeklini değiştirir mi? \\
& 2. & \\
Mıknatııı tanıyalım ve mıknatısın & 3. & Kuvvetin harekete etkisini ölçebilir miyiz? \\
kuvvet ile ilişkisi & 5. & \\
& 1. & Her mıknatısın çekme gücü aynı mıdır? \\
& 2. & Her madde temas gerektiren kuvvete ihtiyaç duyar mı? \\
\hline Ŏğrench & 3. & Mıknatıs her maddeyi çeker mi? \\
& 4. & Mıknatıslar, bölündüğünde veya parçalandığında yine aynı etkiyi gösterir mi? \\
\hline
\end{tabular}

Öğrenciler belirledikleri araştırma sorularını test edebilecekleri deney düzeneklerini grup arkadaşları ile birlikte müzakereler sonucunda karar vermişlerdir. Araştırmacının sınıfa getirmiş olduğu malzemelerden kendi belirledikleri soruyu test edebilecek uygun malzemeleri seçmişlerdir. Örneğin, "Bir yaya uygulanan kuvvet değişirse yayın şeklinde değişiklik olur mu” sorusu için, bir yay ve çeşitli değerdeki kütleleri kullanmışlardır. Test için, öncelikle yayın ilk boyunu ölçmüşler, daha sonra yayın ucuna çeşitli kütleleri takarak yayın boyundaki değişimleri not etmişlerdir.

Öğrenciler belirledikleri sorunun cevabına yönelik yaptıkları deneyler ve gözlemler sonucunda kaydettikleri verileri ve gözlemleri doğrultusunda çıkarımlar yaparak bir iddia ortaya koymuşlar ve iddialarını deliller sunarak desteklemişlerdir. Örneğin "Bir yaya uygulanan kuvvet değişirse yayın şeklinde değişiklik olur mu?" sorusunu test eden gruptaki öğrenciler, gözlemleri 
sonucunda oluşturdukları iddialarını "Kuvvet yayın şeklini değiştirir" olarak ifade etmişlerdir. Kanıt ya da delil olarak ise "Yaya uyguladığımız kuvvet değiştikçe yayın boyunda değişiklikler oldu. Önce yayın ilk boyunu ölçtük ve $5 \mathrm{~cm}$ bulduk. Sonra yaya $20 \mathrm{~g}$ taktık, yayın boyunu tekrar ölçtük ve $27 \mathrm{~cm}$ bulduk. Daha sonra $50 \mathrm{~g}$ taktık, yayın boyu $51 \mathrm{~cm}$ oldu ve en son $250 \mathrm{~g}$ denediğimizde yayın boyu yaklaşık olarak $150 \mathrm{~cm}$ oldu. Kütleyi kaldırdı̆̆ımızda ise yayımızın eski şeklini almadığını gördük, bundan dolayı kuvvetin yay üzerinde şekil değişikliği etkisi olduğuna karar verdik" şeklinde açıklamalarda bulunmuşlardır. Bu şekilde her bir grup kendi sorusunu test etmiş ve gözlemlerine dayalı olarak, müzakereler yaparak kendi iddia ve delillerini oluşturmuşlardır.

АTВÖ raporları, çalışma boyunca derste yapılan toplam üç АТВÖ etkinlikleri sonunda öğrenciler tarafından bireysel olarak doldurulmuştur. Tüm gruplar, doldurmuş oldukları ATBÖ rapor formatındaki bilgileri sınıf arkadaşları ile paylaşmak üzere sunum yapmışlardır. Bu sunumlar sırasında sınıf içi müzakereler devam ederken, öğretmen soruları ile müzakereyi desteklemiştir. Tüm grupların sunumlarından sonra soru-cevap yöntemiyle genel bir toparlama yoluna gidilmiş ve ders özetlenmiştir.

Kontrol grubunda ise, beş hafta boyunca 2018 fen bilimleri dersi öğretim programının ön gördüğü şekilde "Kuvvetin Etkileri" ünitesi işlenmiştir. Kontrol grubu öğretmeni, sıklıkla düz anlatım yöntemi ve soru-cevap tekniği kullanarak, bazen de konu ile ilgili videolar izleterek ve ders kitabında yer alan etkinlikleri öğrencilere yaptırarak derslerini yürütmüştür. Öğretmenin derslerinde, konu anlatımı yanında konu ile ilgili soru çözümlerine de yer verdiği gözlemlenmiştir. Soru çözümlerini ise, ders kitaplarından ve çeşitli kaynaklardan derledikleri çoktan seçmeli sorular ile gerçekleştirmiştir. Soruları önce öğrencilerin yapması için belirli bir zaman vermiş, sonrasında ise öğrenci cevaplarını alarak dönütler verdiği görülmüştür.

\section{Verilerin Analizi}

Araştırma verilerinin analizinde, frekans, ortalama, standart sapma, normallik varsayımının tespiti için Kolmogorov-Smirnov testi (Ön-test için $p=0.159>0.05$; Son-test için $p=0.482>0.05$ ) yapılmış olup normal dağılıma sahip olduğuna karar verilmiş ve varsayımları kontrol edilip onaylanan parametrik testlerden ANCOVA kullanılmıştır.

\section{BULGULAR}

\section{Betimleyici İstatistikler}

Deney ve kontrol grubundaki öğrencilerin ön-test ve son-testten aldıkları puanlara ilişkin ortalama ve standart sapma değerleri Tablo 8'de verilmiştir.

Tablo 8. KEÜBT ile ilgili betimsel istatistikler

\begin{tabular}{lcccc}
\hline Test & Grup & $\mathrm{n}$ & $\overline{\mathrm{x}}$ & $\mathrm{ss}$ \\
\hline \multirow{2}{*}{ Ön-test } & Deney & 22 & 10.82 & 2.95 \\
& Kontrol & 23 & 12.48 & 2.99 \\
\multirow{2}{*}{ Son-test } & Deney & 22 & 15.23 & 1.77 \\
& Kontrol & 23 & 14.48 & 2.29 \\
\hline
\end{tabular}

Tablo 8'de görüldüğü gibi ATBÖ yaklaşımının kullanıldığı deney grubunda, uygulama öncesi test başarı puan ortalaması 10,82 iken bu değer uygulama sonrasında 15,23 olmuştur. Kontrol grubunun uygulama öncesi test başarı puan ortalaması ise 12,48 iken uygulama sonrası bu değerin 14,48 olduğu görülmektedir. Bu bağlamda, ATBÖ yaklaşımının uygulandığı deney grubundaki ortalama artışının daha fazla olduğu anlaşılmaktadır.

Aynı zamanda deney ve kontrol gruplarının ön-test ortalamalarının aralarındaki farkın anlamlılık düzeyinin tespitine yönelik bağımsız t testi uygulanmıştır. Bağımsız t-testi sonuçları Tablo 9'da yer almaktadır.

Tablo 9. Ön-test ortalamalarına ait bağımsız t-testi sonuçları

\begin{tabular}{|c|c|c|c|c|c|c|c|c|}
\hline Ünite & Test & Grup & $\mathrm{n}$ & $\bar{x}$ & SS & sd & $\mathrm{t}$ & $p$ \\
\hline \multirow{2}{*}{ Kuvvetin etkileri } & \multirow{2}{*}{ Ön-test } & Deney & 22 & 10.82 & 2.95 & 43 & -1.87 & 0.068 \\
\hline & & Kontrol & 23 & 12.48 & 2.99 & & & \\
\hline
\end{tabular}

Deney ve kontrol grubunun ön-test puanlarının ortalamalarına ilişkin yapılan bağımsız t testi sonuçlarına göre ise istatistiksel olarak anlamlı bir farka rastlanılmamıştır $[\mathrm{t}(43)=-1.87, \mathrm{p}>0.05]$.

\section{Yordayıcı İstatistikler}

Kovaryans analizini (ANCOVA) yapmadan önce ilk olarak bu analizin tüm varsayımları test edilmiştir. Varsayımlarından biri olan varyansların eşitliği için Levene testine bakılmıştır. Diğer bir varsayımı olan eğimlerin eşitliği için ise asıl etkisi incelenmek istenen bağımsız değişken ile ortak değişken arasındaki etkileşim kontrol edilmiştir. Elde edilen $\mathrm{p}$ değerine bakılarak etkileşimin anlamlı olmadığı anlaşılmıştır. Bağımlı değişken olarak incelenen "Kuvvetin Etkileri Ünitesi Başarı Testi” son-test puanları ile bağımsız değişken olan ön-test puanları arasında yapılan korelasyon analizinde anlamlı $(r=0,58)$ bir ilişki saptandığı için ön-test değişkeni, 
ortak değişken olarak alınmıştır. Böylece tüm varsayımları test edilip onaylanarak yapılan ANCOVA sonuçları da Tablo 10'da verilmiştir.

Tablo 10. ANCOVA sonuçları

\begin{tabular}{lccccc}
\hline $\begin{array}{l}\text { Varyansın } \\
\text { Kaynağı }\end{array}$ & $\begin{array}{c}\text { Kareler } \\
\text { Toplamı }\end{array}$ & sd & $\begin{array}{c}\text { Kareler } \\
\text { Ortalaması }\end{array}$ & $\mathrm{F}$ & \\
\hline Son-test & & & & & \\
Ön-test & 80.97 & 1 & 80.97 & 33.79 & 0.000 \\
Yöntem & 23.84 & 1 & 23.84 & 0.95 & $0.003^{*}$ \\
Hata & 100.62 & 42 & 2.39 & 0.192 \\
\hline
\end{tabular}

ANCOVA sonuçlarına göre, ön-test kontrol edilerek gruplar arası uygulamadan kaynaklı farkın olup olmadığına bakıldığında, son-test puanları arasında deney grubu lehine istatistiksel olarak anlamlı bir fark bulunmuştur $(F(1,42)=9.95, p<0.05)$. Etki büyüklüğü için bakılan eta kare (n2 = 0.192 değeri Green ve Salkind'e (2014) göre "büyük etki" düzeyine denk gelmektedir. Aynı zamanda testin gücü ise 0.869 olarak bulunmuştur.

\section{Deney Grubundaki Öğrencilerin Yazılı Argümantasyon Kalite Düzeylerine ilişkin Bulgular}

Deney grubundaki her bir öğrencinin katıldığı ATBÖ raporları ATBÖ 1, ATBÖ 2 ve ATBÖ 3 şeklinde kodlanmıştır. Öğrencilerin yazılı argümantasyon kalite düzeyleri, Tablo 11'de yer almaktadır.

Tablo 11. Raporlara göre öğrencilerin argümantasyon kalite düzeyleri, öğrenci sayıları ve yüzdeleri

\begin{tabular}{|c|c|c|c|c|c|c|}
\hline \multirow{3}{*}{$\begin{array}{l}\text { Argümantasyon } \\
\text { Düzeyleri }\end{array}$} & \multicolumn{6}{|c|}{ ATBÖ Etkinlikleri } \\
\hline & \multicolumn{2}{|c|}{ ATBÖ 1} & \multicolumn{2}{|c|}{ ATBÖ 2} & \multicolumn{2}{|c|}{ ATBÖ 3} \\
\hline & $f$ & $\%$ & $f$ & $\%$ & $f$ & $\%$ \\
\hline 1. düzey & 0 & 0 & 3 & 13.6 & 0 & 0 \\
\hline 2. düzey & 13 & 59.0 & 4 & 18.1 & 2 & 9.0 \\
\hline 3. düzey & 3 & 13.6 & 3 & 13.6 & 6 & 27.2 \\
\hline 4. düzey & 6 & 27.2 & 12 & 54.5 & 14 & 63.6 \\
\hline 5. düzey & 0 & 0 & 0 & 0 & 0 & 0 \\
\hline
\end{tabular}

Tablo 11'de etkinliklere göre yazılı argümantasyon kalite düzeyleri, ilk etkinlikte öğrencilerin \%59.0'u, 2. düzey yani zayıf argümantasyon seviyesine sahip olarak bulunmuştur. Son etkinlikte ise, öğrencilerin \%63.6'sının argümantasyon kalite düzeyleri 4. düzeye yani güçlü argümantasyon seviyesine çıktığı görülmektedir. Şekil 1'de öğrencilerin argümantasyon düzeylerindeki değişim verilmektedir.

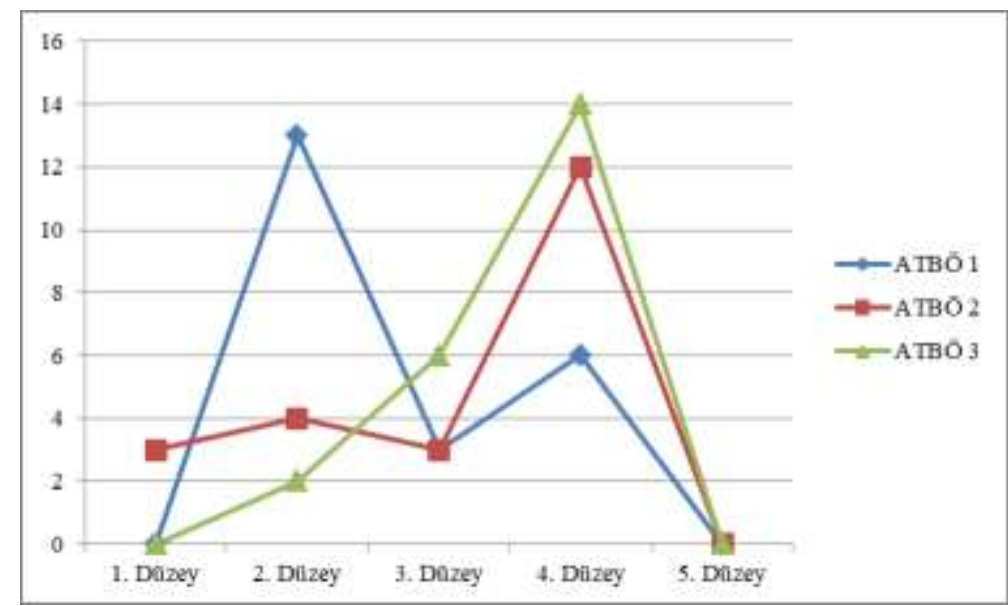

Şekil 1. Öğrencilerin argümantasyon kalite düzeylerindeki değişimi

Öğrencilerin etkinliklerde kullandığı ifadeler belirtilen düzeylerdeki kriterlere göre puanlanmıştır. Her bir ATBÖ raporu için öğrencilerin puan ortalamaları hesaplanmıştır. Şekil 2'de yazılı argümantasyon kalite düzeyleri puan ortalamalarının değişimi verilmektedir. 


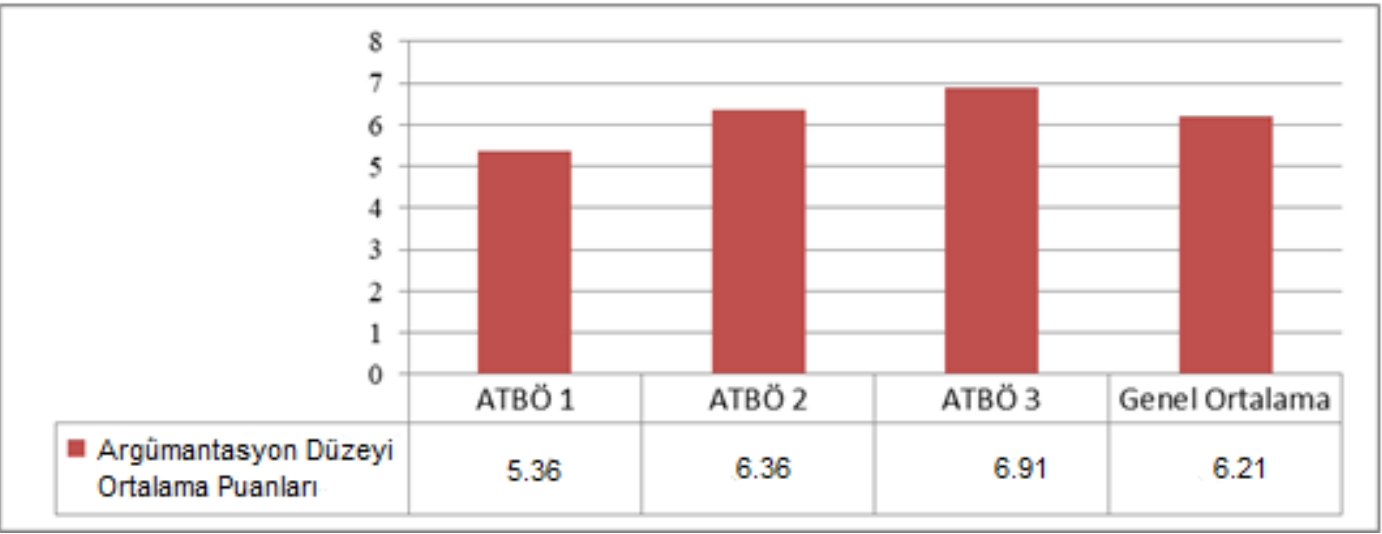

\section{Şekil 2. Yazılı argümantasyon kalite düzeyleri puan ortalamaları}

Şekil 2'de ATBÖ 1 etkinliğinde öğrencilerin argümantasyon düzeyini gösteren ortalama puan değeri 5.36 iken ATBÖ 3 etkinliğinde ortalama puan 6.91'e yükselmiştir. Genel olarak üç etkinlikten aldıkları ortalama puan değeri 6.21 olarak bulunmuştur. Ayrıca Şekil 1'de gösterilen ATBÖ etkinlik düzeylerindeki değişimler, öğrencilerin başlangıçta argümantasyon kaliteleri 2. düzeyde iken, son etkinlikte argümantasyon kaliteleri 4. düzeye çıkmış olması süreç içerisinde argüman üretebilme, yazabilme becerilerinin arttığının ve yapılan etkinlik sayısı arttıkça daha da artabileceğinin bir göstergesidir.

\section{TARTIŞMA}

Bu çalışmada, dördüncü sınıf öğrencilerinin fen eğitiminde bir bilim insanı gibi düşünerek, sorgulayarak ve öğrenilen bilgilerin anlamlı ve kalıcı olması için gerekli olan argümantasyon tabanlı bilim öğrenme yaklaşımının ders başarılarına etkisini belirlemek hedeflenmiştir. Aynı zamanda öğrenmede önemli bir faktör olan yazma etkinliklerinde oluşturdukları yazılı raporların argümantasyon kalite düzeylerini belirlemek amaçlanmıştır.

Alanyazında АТВÖ uygulamalarının farklı sınıf sevilerinde kullanıldığı görülmekle birlikte çalışmaların amacının çoğunlukla, argümantasyonun öğrencilerin öğrenmelerine/akademik başarılarına ya da kavramsal anlamalarına etkisinin değerlendirilmesi şeklinde olduğu görülmektedir (Bağ ve Çalık, 2017; İnam ve Güven, 2019; Kabataş-Memiş, 2017). Bu çalışmalara ilişkin sonuçlar incelendiğinde; fen dersleri argümantasyona dayalı etkinlikler ile yürütüldüğünde, öğrencilerin başarılarının arttığı, kavram ve olgular arasındaki ilişkileri anlayarak öğrendikleri görülmektedir (Akkuş ve Kurt, 2012; Aktaş ve Doğan, 2018; Driver, Newton ve Osborne, 2000; Günel, Hand ve McDermott, 2009; Günel ve Tanrıverdi, 2012; Jang ve Hand, 2017; Jimenez-Aleixandre, BullgalloRodriguez ve Duschl, 1997; Kaya ve Kılıç, 2008; Öğreten ve Uluçınar-Sağır, 2014; Uluçınar-Sağır ve Kılıç, 2012; Yaman, 2018). Çalışma sonuçlarımızın, konuya ilişkin benzer çalışmalarla paralellik arz ettiği görülmüştür. Özetle çalışmada da deney grubundaki öğrencilerin lehine anlamlı bir fark bulunmuştur. Argümantasyon sürecinde bireyler, bilimsel olarak düşünebilmekte, bilgiyi sorgulamakta, üretebilmekte, kendini ifade edebilmekte, kendi bilgisini savunabilmekte, işbirliği halinde çalışımakta ve bilgiyi paylaşmaktadırlar (Yıldırır ve Nakiboğlu, 2014). Bu durum, öğrencilerinin başarılarının sebebi olarak açıklanabilir.

Konuya ilişkin alanyazından örneklem düzeyi ile ilgili ilkokul dördüncü sınıf öğrencilerini kapsayan çalışmaların oldukça sınırlı düzeyde kaldığı anlaşılmıştır (İnam ve Güven, 2019). Bu çalışma ile ilkokullarda argümantasyon ile öğrenme konusundaki alanyazın boşluğuna katkı sağlanmaktadır. Diğer taraftan, çocukların erken yaşlardan itibaren bilimsel aktiviteler hakkında az çok bir bilgiye sahip oldukları ve bilimsel öngörülerin küçük yaşlardan itibaren kazanılmaya başlandığı görülmektedir (Güler ve Akman, 2006). Bu bağlamda ilkokul öğrencilerinin argümantasyon becerilerinin geliştirilmesiyle, ilerleyen eğitim hayatında karşılaşacakları derslerdeki argümantasyon tabanlı öğrenme seviyelerinin artışına katkı sağlanacağı düşünülmektedir.

ATBÖ uygulamaları, bilimsel sorgulama gerçekleştirilirken ortaya çıkan bilimsel argümanı analiz edebilmeyi sağlamaktadır (Choi ve diğ., 2010). Öğrenciler ATBÖ uygulamalarına katılmaları sonucunda ATBÖ öğrenci raporlarını oluşturmuşlardır. Çalışmaya katılan dördüncü sınıf öğrencilerinin ATBÖ raporlarının analiz edilmesi sonucunda yazılı argümantasyon kalitesi "orta düzey" olarak bulunmuş olup, Choi ve diğerlerinin (2010) yaptıkları çalışmanın sonuçları ile paralellik göstermekte olduğu tespit edilmiştir. Argümantasyon ile ilgili etkinliklerdeki sayılar arttıkça öğrencilerin de argüman üretebilme becerilerinin geliştiği bildirilmekte olup (Öğreten ve Uluçınar-Sağır, 2014; Yaman, 2018), bu hususun çalışmamızın sonuçlarıyla örtüştüğü görülmüştür. Erken yaş gruplarında fen öğretimi sağlanırken bilimsel olguların anlaşılması ve ifade edilmesinde bir bilim insanı gibi davranılması açısından yazılı ve sözlü argümantasyonun kullanılması büyük bir öneme sahiptir (Simon ve Johnson, 2008). Bu çalışma, alanyazında erken yaş grupları şeklinde bahsedilmiş olan ilköğretim dördüncü sınıf öğrencileri ile yapılmış olup, argümantasyon etkinliklerinin daha erken yaşlardaki gruplarda ve fen eğitiminde etkili olabileceğini göstermiştir.

Fen bilimleri alanında argümantasyon ile ilgili yapılan araştırmaların konuya göre dağılımları değerlendirildiğinde, çoğunlukla tercih edilen konulardan birinin "kuvvet ve hareket" olduğu görülmüştür (Inam ve Güven, 2019). Ancak aynı zamanda bu ünitenin kavram yanılgılarının daha çok rastlandığı konu olması da dikkat çekici bulunmuştur (Kara ve Aktürkoğlu, 2019). Her iki çalışmanın (İnam ve Güven, 2019; Kara ve Aktürkoğlu, 2019) ortak sonucu olarak, üst sınıflarda bu durumların tespit edildiği saptanmıştır. Mevcut çalışmanın "kuvvet ve hareket" ünitesindeki АTBÖ uygulamalarının, üniteye ait yanılgıların erken eğitim basamağında 
giderilebilme olanağı sunması bakımından önemli olduğu düşünülmektedir. Ayrıca ATBÖ uygulamaları ile "kuvvet ve hareket" ünitesine ait öğrenme çıktılarının küçük yaş gruplarında değerlendirilmiş olması bakımından alana katkı sağlanması mümkün olacaktır.

Argümantasyon konusunda yapılmış olan meta analiz çalışmalarında argümantasyon seviyelerinin genel olarak Toulmin'in (1958) Argümantasyon Modeli kullanılarak analiz edildiği ifade edilmektedir (Bağ ve Çalık, 2017; İnam ve Güven, 2019; KabataşMemiş, 2017). Mevcut çalışmada ise, Toulmin'in argümantasyon modeli yerine Choi ve diğerlerinin (2010) hazırlamış oldukları ölçek kullanılarak argümantasyon seviyeleri analiz edilmiştir. Bu ölçeğin tercih edilmesinin nedeni ise, Choi ve diğerlerinin yaptıkları çalışmalar sonucunda, daha küçük yaş gruplarında bu ölçeğin kullanılmasının daha uygun olacağı sonucuna varmış olmalarıdır.

Bu çalışma sürecinde, uygulama öncesi ve sonrasında iç geçerlik tehditlerini kontrol edebilmek adına çeşitli tedbirler alınmıştır. Uygulama öncesinde öğretmen ve sınıf seviyeleri açısından birbirine benzer özellik gösteren aynı okuldan iki dördüncü sınıf çalışma grubu olarak seçilmiştir. Belirlenen ünite ile ilgili kazanımlar incelenmiş ve bu kazanımlar doğrulusunda ATBÖ yaklaşımının gereği olarak öğretmen ve öğrenci şablonlarına uygun olarak ders planları hazırlanmış ve uygulama süresince hazırlanan planlar kullanılmıştır. ATBÖ etkinliklerini uygulayabilmek için sınıfın fiziki şartları kontrol edilmiş ve bu konuda herhangi bir sıkıntı olacak durum gözlenmemiştir. Ayrıca araştırmacı hem deney hem de kontrol grubunda öğretmenleri gözlemlemiştir.

\section{SONUÇ VE ÖNERILER}

Bu çalışmada "Kuvvetin Etkileri" ünitesinde uygulanan ATBÖ yaklaşımının ilkokul 4. sınıf öğrenci başarısını ve argümantasyon kalite düzeyini artırmada etkili olduğu sonucuna varılmıştır. Bu sonuç doğrultusunda ATBÖ yaklaşımının ilkokulun farklı sınıf seviyelerinde ve farklı fen konularında da uygulanması önerilebilir.

Mevcut araştırmada çalışma grubu bir ilkokuldaki iki sınıf ile sınırlıdır. Bu çalışma daha büyük örneklem gruplarında tekrarlanarak genellenebilirliği artırılabilir. Sonraki çalışmalarda ATBÖ uygulamasına ilişkin ders gözlemleri, öğretmen ve öğrencilerle derinlemesine görüşmeler yapılabilir. Nitel araştırmalar ya da nicel ve nitel verilerin bütünleştirildiği araştırmalar da yapılabilir.

АТВÖ yaklaşımının ilkokul seviyesinde uygulaması sınırlı olduğundan bu yaklaşımın öğrenci başarısı ve argümantasyon becerisi dışında kavramsal anlama, eleştirel düşünme gibi diğer öğrenme çıktıları üzerindeki etkisi de araştırılabilir. ATBÖ uygulamaları model tabanlı öğrenme gibi farklı yöntem ve tekniklerle bütünleştirilerek öğrenme ortamı zenginleştirilebilir ve öğrencilerin argüman kurmaları kolaylaştırılabilir.

Gelecek çalışmalarda ilkokul öğrencilerine öğretmenlik yapan sınıf öğretmenlerine ATBÖ yaklaşımı ile ilgili hizmet içi eğitimler verilebilir. Benzer şekilde geleceğin sınıf öğretmenlerinin öğretim programlarındaki derslerinde ATBÖ yaklaşımı ile ilgili uygulamalara yer verilebilir.

\section{KAYNAKÇA}

Aktaş, T. \& Doğan, Ö. K. (2018). Argümana dayalı sorgulama öğretiminin 7.sınıf öğrencilerinin akademik başarılarına ve argümantasyon seviyelerine etkisi. Mersin Üniversitesi Eğitim Fakültesi Dergisi, 14(2), 778-798.

Akkuş, R. \& Kurt, í. (2012). Argümantasyon tabanlı bilim öğrenme yaklaşımının öğrenci akademik başarısına ve kritik düşünme becerisine etkisi.10. Ulusal Fen Bilimleri ve Matematik Eğitimi Kongresi (UFBMEK), Niğde.

Allen, M. (2010). Misconceptions in primary science. Maidenhead: Open University Press, McGraw-Hill Education.

Anggoro, S., Widodo, A., Suhandi, A. \& Treagust, D. F. (2019). Using a Discrepant Event to Facilitate Preservice Elementary Teachers' Conceptual Change about Force and Motion. Eurasia Journal of Mathematics, Science and Technology Education, 15(8), em1737.

Bağ, H. \& Çalık, M. (2017). İlköğretim düzeyinde yapılan argümantasyon çalışmalarına yönelik tematik içerik analizi. Eğitim ve Bilim, 190(42), 281303.

Cavagnetto, A. R. (2010). Argument to foster scientific literacy: A review of argument interventions in K-12 science contexts. Review of Educational Research, 80(3), 336-371.

Ceylan, K. E. (2012). Illköğretim 5. sını öğrencilerine dünya ve evren öğrenme alanında bilimsel tartısma (argumantasyon) odaklı yöntem ile öğretimi. Yüksek Lisans Tezi. Gazi Üniversitesi, Eğitim Bilimleri Enstitüsü, Ankara.

Champagne, A. B., Klopfer, L. E. \& Anderson, J. H. (1980). Factors influencing the learning of classical mechanics. American Journal of Physics, 48, 1074-1079.

Chen, Y. C. (2013a). Constructing and critiquing arguments. Science and Children, 50(5), 40-45.

Chen, Y.C. (2013b). Writing an argument to a real audience: Alternative ways to motivate students in writing about science. Teaching Science, 59(4), 8-12.

Chen, Y. C. \& Steenhoek, J. (2013a). Arguing like a scientist: Engaging students in core scientific practices. The American Biology Teacher, 76(4), 231-237.

Chen, Y. C. \& Steenhoek, J. (2013b). A negotiation cycle to promote argumentation in science classrooms. Science Scope, 36(9), 41-50.

Chen, Y. C., Hand, B. \& McDowell, L. (2013). The effects of Writing-to-learn activities on elementary students' conceptual understanding: Learning about force and motion through writing to older peers. Science Education, 97(5), 745-771. 
Choi, A., Notebaert, A., Diaz, J. \& Hand, B. (2010). Examining arguments generated by year 5, 7 and 10 students in science classrooms. Research in Science Education, 40(2), 149-169.

Çepni, S., Aydın, A. \& Ayvacı, H. Ş. (2000). Dört ve beşinci sınıflarda fen bilgisi programındaki fizik kavramlarının öğrenciler tarafından anlaşııma düzeyleri. IV. Fen Bilimleri Eğitim Kongresi, Ankara.

Çepni, S., Bayrakçeken, S., Yılmaz, A., Yücel, C., Semerci, Ç., Köse, ... Gündoğdu, K. (2008). Ölçme ve Değerlendirme. Ankara: Pagem Akademi.

Driver, R., Newton, P. \& Osborne J. (2000). Establishing the norms of scientific argumentation in classrooms. Science Education, 84(3), 287-312.

Erduran, S. \& Jiménez-Aleixandre, M. P. (Eds.). (2007). Argumentation in science education: Perspectives from classroom-based research. Dordrecht, The Netherlands: Springer.

Frankel, J. R. \& Wallen, N. E. (2006). How to design and evaluate research in education. New York: McGraw-Hill Inc.

Fraenkel, J., Wallen, N. \& Hyun, H. (2012). How to design and evaluate research in education (8rd ed.). New York: McGrawHill, Inc.

Fulwiler, B.R. (2011). Writing in science in action. Portsmouth, NH: Heinemann.

Green, S. B. \& Salkind, N. J. (2014). Using SPSS for windows and Macintosh: Analyzing and understanding data. New Jersey: Upper Saddle River.

Güler, T. \& Akman, B. (2006). 6 yaş çocuklarının bilim ve bilim insanı hakkındaki görüşleri. Hacettepe Üniversitesi Eğitim Fakültesi Dergisi, 31(31), $55-66$.

Günel, M., Hand, B. \& McDermott, M. (2009). Writing for different audiences: Effects on high school students' conceptual understanding of biology. Learning and Instruction, 19(4), 354-367.

Günel, M., Kıngır, S. \& Geban, Ö. (2012). Argümantasyon tabanlı bilim öğrenme (ATBÖ) yaklaşımının kullanıldığı sınıflarda argümantasyon ve soru yapılarının incelenmesi. Eğitim ve Bilim, 37(164), 316-330.

Hand, B. (Ed.). (2008). Science inquiry, argument and language: A case for the science writing heuristic. Rotterdam: The Netherlands, Sense.

Günel, M. \& Tanrıverdi, K. 2012). Boylamsal araştırma projesi: Hizmetiçi eğitim ve sınıf içi uygulamalarının, öğretmen pedagojisine, öğrenci akademik başarısına, düşünme becerilerine etkisinin araştırılması. 10.Ulusal Fen Bilimleri ve Matematik Eğitimi Kongresi (UFBMEK), Niğde.

Hand, B., Norton-Meier, L. \& Jang, J. Y. (Eds.). (2017). More voices from the classroom: International teachers' experience with argument-based inquiry. Rotterdam: Sense Publishers.

Hand, B., Norton-Meier, L., Staker, J. \& Bintz, J. (2009). Negotiating science: The critical role of argument in student inquiry, grades 5-10. Portsmouth, NH: Heinemann.

Hand, B., Wallace, C. W. \& Yang, E. (2004). Using a science writing heuristic to enhance learning outcomes from laboratory activities in seventhgrade science: Quantitative and qualitative aspect. International Journal of Science Education, 26(2), 131-149.

Hillocks, G. (2011). Teaching argument writing, grades 6-12. Portsmouth, NH: Heinemann.

Hohensell, L. M. \& Hand, B. (2006). Writing-to-learn strategies in secondary school cell biology: A mixed method study. International Journal of Science Education, 28(2-3), 261-289.

İnam, A. \& Güven, S. (2019). Argümantasyon yönteminin kullanıldığı deneysel çalışmaların analizi: Bir MetaSentez Çalışması. The Journal of International Lingual, Social and Educational Sciences, 5(1), 155-173.

Jang, J. \& Hand, B. (2017). Examining the value of a scaffolded critique framework to promote argumentative and explanatory writings within an argument-based inquiry approach. Research in Science Education, 47(6), 1213-1231.

Jimenez-Aleixandre, M. P., Bullgallo-Rodriguez, A. \& Duschl, R. A. (1997). Argument in high school genetics. Paper presented at the National Association for Research in Science Teaching, Chicago, IL.

Kabataş-Memiş, E. (2017). Türkiye'de argümantasyon konusunda gerçekleştirilen tezlerin analizi: Bir meta-sentez çalışması. Cumhuriyet International of Education, 6(1), 47-65.

Kara, S. \& Aktürkoğlu, B. (2019). Illkokul fen bilimleri ders kitaplarında kavram yanılgılarına neden olabilecek sözel ve görsel içerik. Necatibey Eğitim Fakültesi Elektronik Fen ve Matematik Eğitimi Dergisi (EFMED), 13(1), 234-259.

Kaya, O. N. \& Kılıç, Z. (2008). Etkin bir fen öğretimi için tartışmacı söylev. Ahi Evran Üniversitesi Kırşehir Eğitim Fakültesi Dergisi, 9(3), 89-100.

Keys, C. W., Hand, B., Prain, V. \& Collins, S. (1999). Using the science writing heuristic as a tool for learning from laboratory investigations in secondary science. Journal of Research in Science Teaching, 36(10), 1065-1081.

Kuhn, D. (2010). Teaching and learning science as argument. Science Education, 94(5), 810-824.

Lemke, L. (1990). Talking science: Language, learning, and values. Norwood, NJ: Ablex.

Macaroğlu, E. \& Şentürk, K. (2001). Çocukta yüzme ve batma kavramlarının gelişimi. Yeni Bin Yılın Başında Türkiye'de Fen Bilimleri Eğitimi Sempozyumu, ìstanbul.

Mason, L. \& Boscolo, P. (2000). Writing and conceptual change. What changes? Instructional Science, 28(3), 199-226.

Milli Eğitim Bakanlığı (MEB) (2013). Fen bilimleri dersi öğretim programı. Ankara: Talim Terbiye Kurulu Başkanlığı. [Çevrim-içi: http://mufredat.meb.gov.tr/Dosyalar], Erişim tarihi: 30.12.2017.

Milli Eğitim Bakanlı̆̆ı (MEB) (2018). Fen bilimleri dersi öğretim programı. Ankara: Talim Terbiye Kurulu Başkanlığı. [Çevrim-içi: http://mufredat.meb.gov.tr/Dosyalar], Erişim tarihi: 30.12.2017.

Norton-Meier, L., Hand, B., Hockenberry, L. \& Wise, K. (2008). Ouestions, claims, and evidence: The important place of argument in children's science writing, Portsmouth, $\mathrm{NH}$ : Heinemann.

Nuhoğlu, H. (2008). Evaluation of the secondary school pupils' view about force and motion. Inönü University Journal of the Faculty of Education, 9(16), 123-140. 
Öğreten, B. \& Uluçınar-Sağır, Ş. (2014). Argümantasyona dayalı fen öğretiminin etkinliğinin incelenmesi. Türk Fen Eğitimi Dergisi, 11(1), 75-99.

Özmen, H., Dumanoğlu, F. \& Ayas, A. P. (2000). Orta öğretimde enerji kavramının öğretimi ve enerji eğitimi. IV. Fen Bilimleri Eğitim Kongresi, Ankara.

Palmer, D. (2001). Students' alternative conceptions and scientifically acceptable conceptions about gravity. International Journal of Science Education, 23(7), 691-706.

OECD (2014). PISA 2012 Results: Creative Problem Solving: Students' Skills in Tackling Real-Life Problems (Volume V), PISA, OECD Publishing. http://dx.doi.org/10.1787/9789264208070-en.

Simon, S. \& Johnson, S. (2008). Professional learning portfolios for argumentation in school science. International Journal of Science Education, $30(5), 669-688$.

Sönmez, G., Geban, O. \& Ertepınar, H. (2001). Altıncı sınıf öğrencilerinin elektrik konusundaki kavramları anlamalarında kavramsal değişim yaklaşımının etkisi. Yeni Bin Yılın Başında Türkiye'de Fen Bilimleri Eğitimi Sempozyumu, İstanbul.

Toulmin, S. (1958). The uses of argument. New York: Cambridge University Press.

Uluçınar-Sağır, Ş. \& Kılıç, Z. (2012). Analysis of the contribution of argumentation-based science teaching on student success and pertinence. Eurasian Journal of Physics and Chemistry Education, 4(2), 139-156.

Wellington, J. \& Osborne, J. (2001). Language and literacy in science education. Philadelphia, PA: Open University Press.

Yaman, F. (2018). Effects of the science writing heuristic approach on the quality of prospective science teachers' argumentative writing and their understanding of scientific argumentation. International Journal of Science and Mathematics Education, 16(3), 421-442.

Yıldırır, H. E. \& Nakiboğlu, C. (2014). Kimya öğretmen ve öğretmen adaylarının derslerinde kullandıkları argümantasyon süreçlerinin incelenmesi. Abant Izzet Baysal Üniversitesi Eğitim Fakültesi Dergisi, 14 (2), 124-154. 
Ek-1: Gizemli bir olay: Bay Deniz, merdivenlerden düştü mü, düşürüldü mü?’ Etkinliği

\section{Gizemli Bir Olay: Bay Deniz, Düştü mü Düşürüldü mü?}

Bir Gizemi Çözme: Gözlemler, Iddialar, Kanıt ve Hesaplar

Siz ve arkadaşınız, zenginliği ve sessiz yapısı ile oldukça iyi bilinen zengin fakat tuhaf bir adam olan Bay Deniz'in merdivenlerden düşme durumunu incelemek üzere kiralanmış olan özel dedektiflersiniz. Hastanede baygın bir şekilde yatmakta olan Bay Deniz, merdivenlerden düşmüş müdür? Yoksa düşürülmüş müdür? $O$, her gece akşam yemeği olarak az pişmiş köfte ve fırında pişmiş iki patates yerdi ve üzerine mutlaka vişne suyunu içerdi. $O$, her zaman endişe ve korku hisleriyle dolu olduğundan insanların etrafında bulunmaktan kaçınmıştır. Onun aynı zamanda paranoya rahatsızığı olduğu da bilinmektedir. Hizmetlilerinin ona karşı gizli bir şekilde komplo kuruyor olmalarından korktuğu için işe aldığı hizmetlilerini uzun zamandır işten çıkarmayı düşünmektedir.

Size, olay yerine varmanızın üzerine, Bay Deniz'in akşam karısı ile tartışmış olduğu ve karısının o akşam bir kulübe katılmak üzere evden ayrıldığı bilgisi verilmiştir. Karısı eve döndüğünde, Bay Deniz'i merdivenlerin aşağısında sırt üstü bir şekilde elinde vişne suyu bardağı ile yatar bir durumda bulduğunu söylemiştir. Aşçıın Bay Deniz için her zamanki yemeği hazırladığı dün akşam, korkunç fırtına olmasından dolayı, Bay Deniz hizmetlilerin evlerine sorunsuz dönebilmeleri için onlara erkenden izin vermişti.

Siz, odanın içine bakarak incelemelerinize başladınız. Yemek odasındaki büyük pencere camı kırılarak paramparça olmuştur. Cam dışarıdan darbe ile kırılmış gibi görünmektedir. Bay Deniz'in vücudunda kesik yaraları teşhis edilmekte ve merdivenin aşağısında sırt üstü yatmaktadır. Ayrıca, tam buradayken altındaki halının üzerinde büyük kırmızı bir leke göze çarpmaktadır. Açılmış vaziyette bir şişe vişne suyu ve bir kısmı yenmiş bir köfte masanın üzerinde durmaktadır. Ayrıca hemen yanında devrilmiş bir sandalye ve masanın altında üzerinde kan olan bir bıçak görülmektedir.

Tüm bu bilgilerle, Bay Deniz'in kendisinin mi düştüğünü, ya da düşürüldüğüne karar vererek tek bir iddia ortaya koyunuz. Iddianıza yönelik olarak, düşürüldü ya da düştü ise kimin yaptığı-olayın nasıl olmuş olabileceği konusunu açıklayabilecek destekleyici kanıt ya da kanıtlar sununuz. Söz konusu iddia ve kanıtı olayların gelişim senaryosu içinde anlatınız. 
Ek- 2: Argümantasyon Tabanlı Bilim Öğrenme Rapor Formatı

\section{ARGÜMANTASYON TABANLI BILIM ÖĞRENME RAPOR FORMATI}

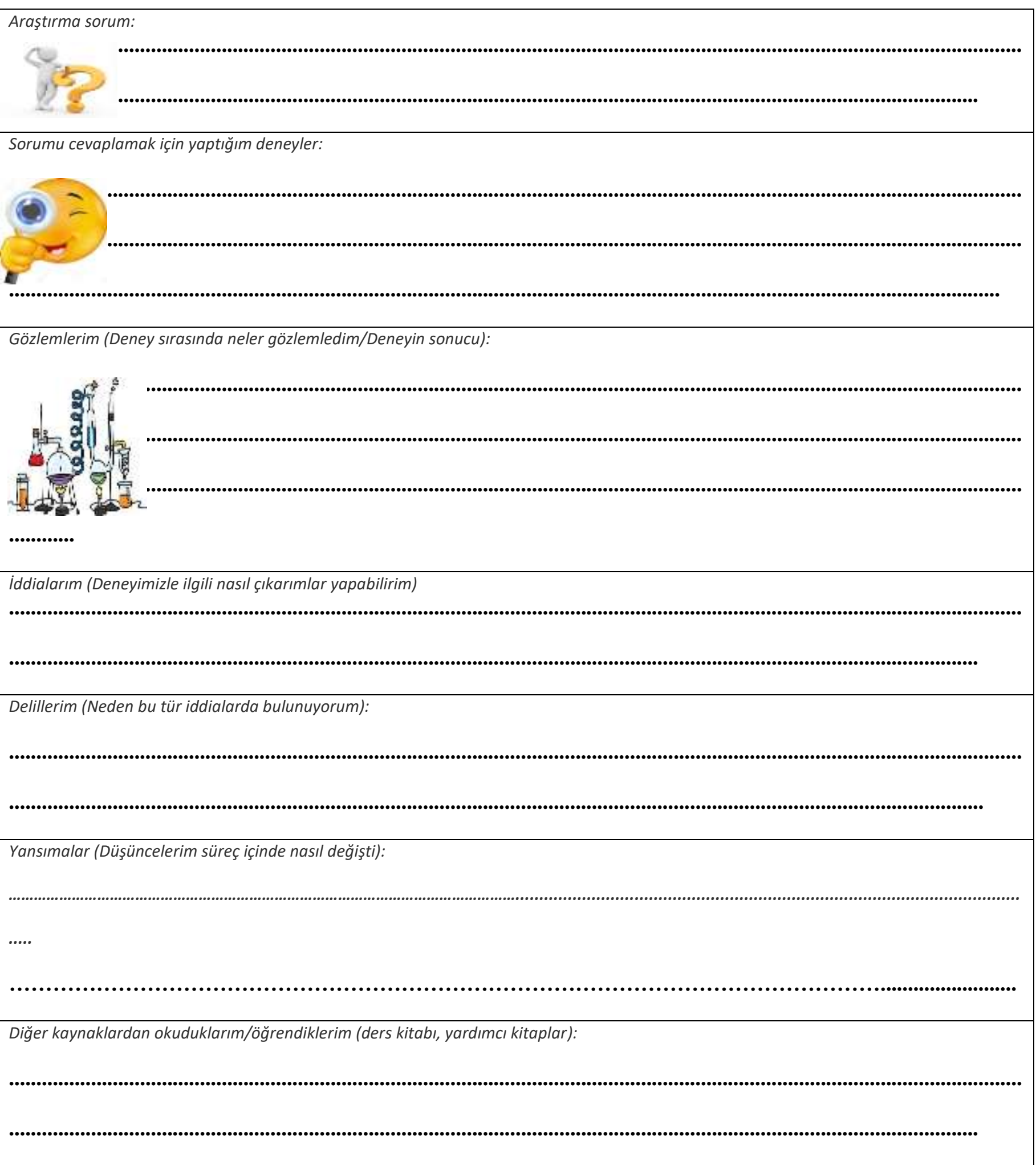

